\title{
ECONOMIC DISPARITIES AMONG THE WORKERS OF AGATE INDUSTRY - A CASE STUDY OF KHAMBHAT IN GUJARAT
}

\author{
Mr. Mahesh Patel \\ \& \\ Dr. J. G. Rangiya
}

\begin{abstract}
- ABSTRACT
Occupational status is a fundamental measure of socio-economic level of living in the society and the occupational structure of agate workers is an important aspect of economic development of Agate industry in the Khambhat region. This paper brings out the discussion of the occupation of the agate workers and its various issue and problems related to local disparities in the Khambhat taluka which is the part of Gulf of Khambhat (also known as Gulf of Cambay) has been constituted as the separate taluka of Anand district in state of Gujarat in the October of 1997. The paper captures the perception of agate workers on various challenges and problems they are facing in the Khambhat taluka of Gulf of Khambhat region. It also investigates solutions that are suggested by the agate workers for their own improvement in the Agate Industry. The concerns and issues that the Agate workers are facing with regards to local disparities in the occupational structure have been briefly analysed for this paper.
\end{abstract}

\section{- KEYWORDS}

Agate Workers, Occupational Structure, Agate Industry, Khambhat Region

\section{- INTRODUCTION}

Agates are basically hard semi-precious stones which are a different physical form of Chalcedony ${ }^{1}$, a kind of silicon dioxide in the form of microscopic fibrous quartz crystals. It is used as a gemstone in ornaments and found all over the world in places including India, Asia, USA, Africa, Brazil, Germany, Mexico, Italy an Nepal. It is found in a variety of colours and gets formed in the cavity of host rocks. This leads to the concentric band kind of formation and appearance of these rocks (Changrani, 2016).

\footnotetext{
${ }^{1}$ It is a fibrous microcrystalline type of silica which contains miniscule crystals of quartz. It is the family name which has many different gemstone varieties in it.
} 
Agate is considered to be unique and different from other gemstones. Worldwide, agate is considered to have metaphysical properties. It is believed that it can enhance the quality of life or even prevent and cure psychological and mental disorders. People also believe that it can balance energies in the human body. Due to this, agates have been extensively mined, shaped, ground and polished multiple times into beads of all shapes and sizes. Agate's value was quite high in antiquity, when it was used as one of the main gemstones. Now its value is fairly low because of global competition around the world. Some 3000-3500 years ago the ancient, Egyptians sought colourful agates and other Chalcedonies from the Aghates River now called the Drillo River in Sicily. As a consequence, many artefacts, jewellery, jewels were found in the tombs of Kings and Queens of ancient Egypt. (Agate, 2007) Agate rates a 6.5 to 7 on the hardness scale. The typical or more common colour of agate is a blue whitish grey. The most highly prized forms of agate are Cornelian, Chrysoprase, Jasper, and Sard. Carnelian is yellow-orange to orange red and translucent. Chryoscolla is an intense light blue or blue green. Chrysoprase is translucent, light to medium yellowish green, and was once considered to be prized form of Jade bloodstone is another version of agate, opaque and dark green with spots of dark red. Jasper can show various landscape-like patterns with the stone.

Currently, agate mines are prevalent all around the world. The important mines are in USA, Russia, Canada and Europe, apart from India. In India, many varieties of agate are found such as the Jasper, bloodstone, chocolate stone, maimariam, azure, jet and Pijora varieties. These are found in parts of Bombay, Chennai and in the state of Orissa. However, it is found predominantly in Khambhat, in the western part of Gujarat. There are four types of agate found in this region. The first is the common agate which is of two types. The white, half clear stone is called Dola, and the cloudy, streaked one is called Jamo. The second is the moss type agate, which is from Tankara near Morvi known as Suabhaji and Phatak. The third variety is that of Kapadvanj, which is from the river bed of Majam known as Kaiyu, Agiyu and Ratadiyu. The most valued of them all is the veined variety of agate, called as the Doradar. However, it is to be noted that India has been the primary exporter of agate products world over and continues to dominate the same till date (PT, 2013).

Gulf of Khambhat is rich in natural reserves such as dolomite, limestones and other stones. The availablity of these minerals have been one of the main criteria for locating specific industries at particular locations. Also the advatange of having established industry of agate since last couple of centuries plays a phenomenal role of establishment of other industries. Since access to port has linkages to the global economy. Many goods and commodities can be send through ships and ports in and around the globe as it is cheaper compared to air logistics.

The predominant occupation of people with agate industry here has been manufacturing and trading of the agate stones. There are many small industrial units in this region, which employ thousands of people and whole communities in cutting, drying, grinding and polishing of agates (PT, 2013). These communities were traditionally called Siddis and they had to take a lease to mine in this area from the Government of India. Siddis were originally from Africa and were one of the first communities to start mining in the Rajpipla mines. Agate have been shaped and polished into various products in Gujarat and especially in 
Khambhat area since many centuries. Agate is a silicate quartz that produces a fine dust when shaped and polished. It is well known that an exposure to crystalline silica give rise to silicosis. Many of the workers who are involved in polishing and shaping business are usually working from their own homes, because of the exposure to silica they and their whole families are affected. Khambhat has come into limelight because of deaths related to agate industry. These home based workers are part of unregulated economy and the workers and their families do not have access to formal economy's service and benefits. Many studies have already been done in the various domains related to the agate industry.

- STUDY AREA

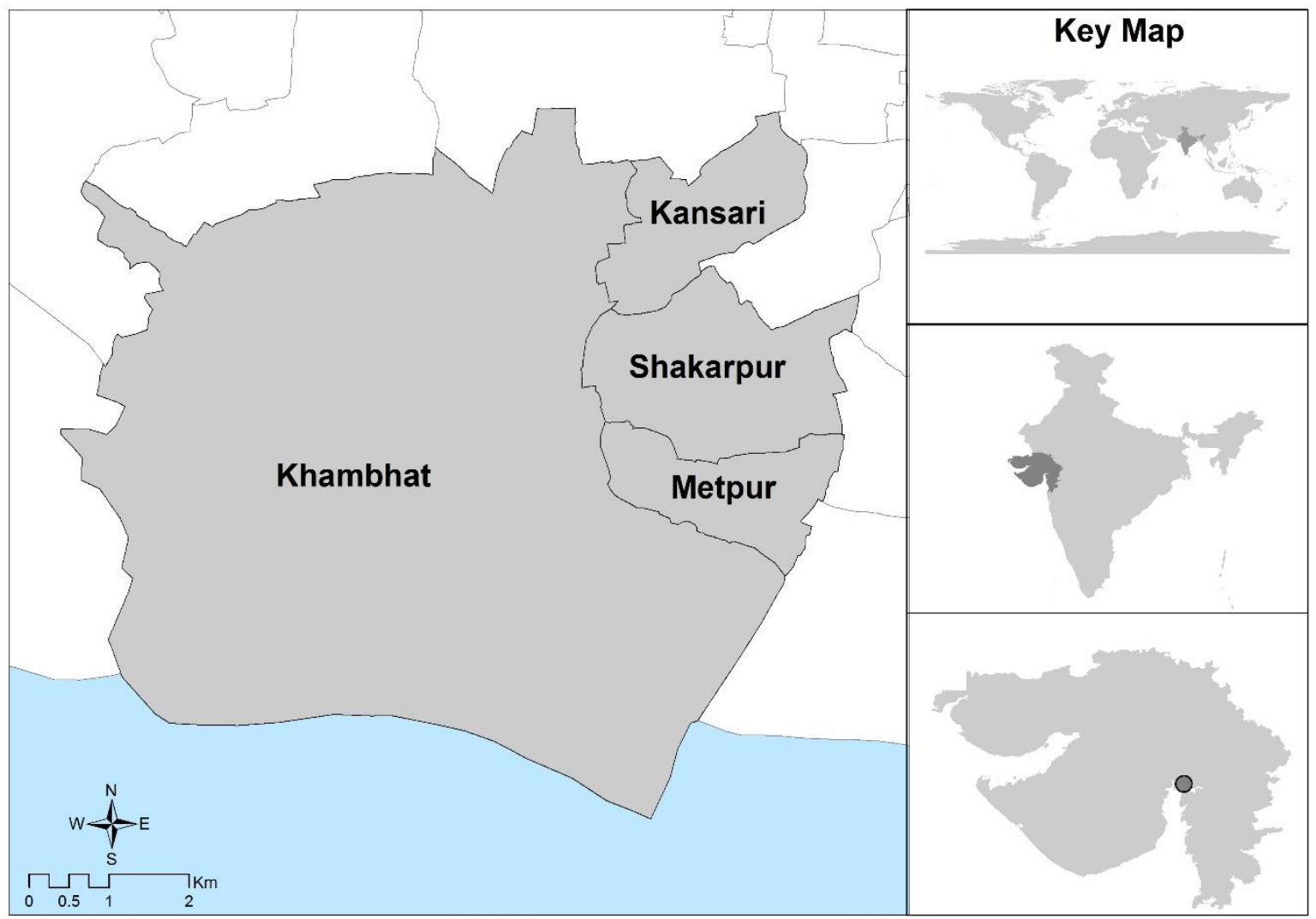

Figure 1

Gulf of Khambhat also known as Gulf of Cambay (Latitude: $22^{\circ} 10^{\prime} 0.60 " \mathrm{~N}$; Longitude: $72^{\circ}$ $25^{\prime} 11.39^{\prime \prime}$ E), is the south-north penetration of Arabian Sea on the west border of India segregating the Saurashtra peninsula and Gujarat mainland. The width is merely $24 \mathrm{Km}$ in the north and it widens like a fan towards the south with a length of $190 \mathrm{Km}$. The gulf receives many rivers Mahi, Narmada, Sabarmati, and Tapi. The gulf encompasses estuaries, mangroves, creeks and sprawling intertidal mudflats as its biodiversity. Excessive industrialization and development in this area has led to the degradation of its natural environment. (Vincent \& Gupta, 2002) The high tidal range in the gulf of Khambhat has 
given this area a vast region of mudflats, up to $3262 \mathrm{sq} . \mathrm{km}$. The mangroves here are seen to be sparse and stunted.

The study pertains to the well demarcated socio-economic and physical geographic region, comprising of the central part of Gujarat of the western India. Khambhat taluka is one of the 8 talukas located over the southern part of the Anand. It is situated between $22^{\circ} 19^{\prime} 5.0988^{\prime \prime} \mathrm{N}$ latitude and $72^{\circ} 37^{\prime} 8.3568^{\prime \prime} \mathrm{E}$ longitude, the talukas is one of the part that forms Gulf of Khambhat of Gujarat. The region consisted of Khambhat taluka is divided into 57 villages. The total are of Khambhat taluka is $1,111.29$ sq. km. The region representing the silting and lo-lying area the district having 50 meters height above sea level.

As per census 2011, Khambhat taluka has 56,867 households with a population of 2,85,69 out of which 1,37,276 are female and 1,48,403 are male population. The population of children (0-6 age) is 34,582 , which is about $12.11 \%$ of the total population. The sex ration of the taluka of Khambhat is around 925 to 1000 compared to Gujarat state of 919.The literacy rate of Khambhat taluka is $71.77 \%$ of which $64.76 \%$ are females and $78.26 \%$ are males. with population density of $257 \mathrm{sq} . \mathrm{km}$. Out of the total population $65.29 \%$ of the population lives in urban area and rural area comprises of $34.71 \%$. There are $6.97 \%$ Scheduled Caste (SC) and $0.85 \%$ Scheduled Tribe (ST) of total population of Khambhat taluka.

\section{- METHODOLOGY AND DATA SOURCE}

The present study is based on both primary and secondary data sources. It takes a mix methodology route, wherein qualitative, quantitative, interview, and cartographic tools are utilized to comprehend the local disparities in the occupational structures of Agate workers in Agate industry in Khambhat region. The primary data was collected through structured questionnaire survey and semi structured interviews. The final questionnaire that is prepared is for the workers of Gulf of Khambhat region. There are three section to the questionnaire for the workers. The first section of the questionnaire deal with socio-economic scenario. The second section deals with the type of work the workers are involved in. And the last section belongs the problems and suggestion that workers faces.

For conducting primary survey of the questionnaire and semi-structured interview of the workers, two major parameters were taken into consideration i.e. the type of work the worker is involved in and the area where the worker works and $10 \%$ of total population is considered as sample size. Utilizing the above two parameters, random sampling method was applied at time of the primary survey. Thus to cover all the types of workers from the agate industry for primary survey. The semi-structured interview with the workers involved the following broad questions: the problems both the workers and traders faces in the industry, related to the work type, infrastructure provisions for workers, safety equipment, provisions for the workers, health problems that workers faces and provision and steps taken to reduce the issues, government policy and law for the workers, steps taken for environmental protection and ultimately suggestions from the workers to improve the situation of agate industry.

On the other hand for further understanding secondary data are collected from various sources which includes published work, unpublished work, reports, thesis, books, journals, 
newspapers, and resources from internet. The data was analysed using statistical techniques and spatial techniques.

\section{- RESULTS AND ANALYSIS}

\section{Demographic Structure of Agate Workers}

In order to understand the caste, religion and other demographic profiles of the region. Various forms of data were collected at the time of the survey. The total population of family members on average was 4.97 per family. The maximum number of family identified was 15 members in a family. The lowest is one. The mean of educated members is 2.96 Per family the average children recorded is 2.35 . The maximum children recorded in a family is 10 . Among the children how many children went to the school on average is 1.88 . Out of average family of 4.97 , the members working in the family is 2.18 and out which only 1.60 members work in agate industry.

$57.4 \%$ of the respondent were male and the remaining $42.6 \%$ people belong to the female. On average 1.66 males are in to agate work from the family, and similar to that female are 1.51 . The average age of experience of male workers in agate work is 15.68 years where as for the female it comes to 13.55 years. Exposure to more than 5 to 10 years of experience in agate industry can lead to serious exposure to silicosis. The (Figure 2) portrays that there are 5 caste that have highest percentage of involvement in the agate work industry. The Thakor caste is the highest found at the time of the survey $(23.8 \%)$. Followed by Chunar caste $(15.1 \%)$. Baraiye caste has $11.4 \%$ people working in the agate industry. Malek and Shekh caste are around $10.4 \%$ and $10.7 \%$ respectively. The other workers comes from various different caste from the society across the whole Gulf of Khambhat region.

The religious distribution at the time of the survey was found skewed towards Hindu religion. $65.1 \%$ people from the total sample survey size of 298 agate workers were coming from the background of Hindu religion. Whereas almost half of that $33.6 \%$ belong to Muslim religion. On average 1.67 people are working in agate work from Hindu religion and average of 1.42 comes for people from Muslim religion. Agate workers are coming majorly from both these religious group. People from other religious group such as Sikh, Christians, etc. Have never been found at the time of survey. Many in their research have acknowledged that Hindus and Muslims have been part of the agate industry since couple of century. Though there haven't been many studies on the subject. The marital status of this worker was largely divided into 4 categories in Descending order of the distribution. Married workers were the highest at $77.9 \%$, followed by $16.8 \%$ workers were unmarried. Widow and Widower turned around to be at $4.7 \%$ and $0.7 \%$ respectively among the sample size. $84.3 \%$ of the agate workers had primary education. Followed by Secondary education at $14.7 \%$ and Higher Secondary education was merely $0.7 \% .0 .3 \%$ is the lowest percentage belonged to Graduation and PostGraduation education level in the agate workers. Education is getting costlier thus the workers are struggling to provide education even for their children. Silicosis on the other hand takes majority of the income, there is merely small amount of money left with the 
worker to support his or her children's education. The total monthly income is utilized largely for food and other household expenses.

Majority of the people (82.6\%) agate workers had their major family source of income from agate work. Few worked with a combination of Agate work and Labour work (11.4\%). The remaining major source of family income was observed among agate business, farming, and labour work. See Table (1) for more details.

Table 1 Major Source of Family Income

\begin{tabular}{|l|r|r|r|}
\hline & \multicolumn{1}{|c|}{$\begin{array}{c}\text { Frequency } \\
\text { (No. of Workers) }\end{array}$} & $\begin{array}{c}\text { Percent } \\
\text { (Source of FI) }\end{array}$ & Cumulative Percent \\
\hline Agate & 246 & 82.6 & 82.6 \\
\hline Agate Business & 1 & .3 & 82.9 \\
\hline Agate, Farming and Labour Work & 2 & .7 & 83.6 \\
\hline Agate and Labour Work & 34 & 11.4 & 95.0 \\
\hline Farming & 1 & .3 & 95.3 \\
\hline Labour Work & 298 & 4.7 & 100.0 \\
\hline Total & 298.0 & 100.0 \\
\hline
\end{tabular}

Type of business ownership was highly skewed towards personal work that the workers did. $68.1 \%$ of the workers had their own personal work for agate. There were small amount of workers who worked personally but also owned the business in person (17.1\%). Only two percent of the workers worked in partnerships (See Table 2 for more details).

Table 2 Type of Business Ownership

\begin{tabular}{|l|r|r|r|}
\hline & \multicolumn{1}{|c|}{$\begin{array}{c}\text { Frequency } \\
\text { (No. of Workers) }\end{array}$} & $\begin{array}{c}\text { Percent } \\
\text { (Business Own.) }\end{array}$ & Cumulative Percent \\
\hline Partnership & 6 & 2.0 & 2.0 \\
\hline Personal & 203 & 68.1 & 70.4 \\
\hline Personal and Privately Owned & 51 & 17.1 & 87.5 \\
\hline Privately Owned & 37 & 12.4 & 100.0 \\
\hline Total & 297 & 99.7 & \\
\hline
\end{tabular}

More than quarter of workers $(30.9 \%)$ worked in stone breaking work at the time of the survey. Followed by $21.8 \%$ of people in stone piercing work. And polishing worked stood at $18.5 \%$. The work distribution identifies the work opportunity the workers have but on the other hand the industry is requires skill worker with enough experience to work in particular type of agate work. For more details (See Table 3). On average the worker spends around 7.14 hours a day in their work. The minimum hours recorded at time of the survey was 4 hours. Majority (69.1\%) of the workers work from morning 1000 hours to evening 1800 hours. Almost 8 hours a day. In month of July to September especially during rainy season more than quarter (23.2\%). Followed by months from July to August (17.8\%).

Table 3 Type of Agate Work

\begin{tabular}{|l|r|r|r|}
\hline & \multicolumn{1}{|c|}{$\begin{array}{c}\text { Frequency } \\
\text { (No. of Workers) }\end{array}$} & $\begin{array}{c}\text { Percent } \\
\text { (Type of Agate Work) }\end{array}$ & Cumulative Percent \\
\hline Drum & 12 & 4.0 & 4.0 \\
\hline Polish & 55 & 18.5 & 22.5 \\
\hline Stone Breaking & 92 & 30.9 & 53.4 \\
\hline Stone Cutting & 30 & 10.1 & 63.4 \\
\hline
\end{tabular}


Towards Excellence: An Indexed, Refereed \& Peer Reviewed Journal of Higher Education / Mr. Mahesh Patel \& Dr. J.G. Rangiya / Page 215-228

\begin{tabular}{|l|r|r|r|}
\hline Stone Piercing & 65 & 21.8 & 85.2 \\
\hline Stone Rolling & 44 & 14.8 & 100.0 \\
\hline Total & 298 & 100.0 & \\
\hline
\end{tabular}

More than $1 / 3^{\text {rd }}(41.6 \%)$ of the workers falls under the income bracket of ₹3000 - ₹6000. Followed by workers who have monthly income of less than ₹3000 (33.9\%). There are very few workers who are paid more than ₹ 12000 a month. For more details of monthly income of workers (See table 4). The workers are paid based on piece they create on daily basis and also on type of work they hold onto. The workers are not allowed to work for other workers. So it is tough for them to create a new source of income apart from agate work. The agate work pays of their daily bills thus many families prefer to stay in agate industry and also allow their children to follow the same path.

Table 4 Monthly Income of Agate Workers

\begin{tabular}{|l|r|r|r|}
\hline & \multicolumn{1}{|c|}{$\begin{array}{c}\text { Frequency } \\
\text { (No. of Workers) }\end{array}$} & $\begin{array}{c}\text { Percent } \\
\text { (Monthly Income) }\end{array}$ & Cumulative Percent \\
\hline 3 to 6k & 124 & 41.6 & 42.3 \\
\hline 6 to 9k & 57 & 19.1 & 61.8 \\
\hline 9 to 12k & 10 & 3.4 & 65.2 \\
\hline Less than 3k & 101 & 33.9 & 99.7 \\
\hline More than 12k & 1 & .3 & 100.0 \\
\hline Total & 293 & 98.3 & \\
\hline Total & 298 & 100.0 & \\
\hline
\end{tabular}

For around $49 \%$ of the families of the agate worker the whole family earns between ₹5000 $₹ 10000$ a month. Close to quarter, 23.5\% families earns less than ₹5000 a month. Income segregation is seen because of the type of work the workers are involved into (See Table 5).

Table 5 Total Family Income (Per Month)

\begin{tabular}{|l|r|r|r|}
\hline & \multicolumn{1}{|c|}{$\begin{array}{c}\text { Frequency } \\
\text { (No. of Workers) }\end{array}$} & $\begin{array}{c}\text { Percent } \\
\text { (Total FI per month) }\end{array}$ & Cumulative Percent \\
\hline 10 to 15k & 58 & 19.5 & 20.3 \\
\hline 5 to 10k & 146 & 49.0 & 91.3 \\
\hline Less than 5k & 70 & 23.5 & 100.0 \\
\hline More than 15k & 12 & 4.0 & 96.0 \\
\hline Total & 286 & 100.0 & \\
\hline Total & 298 & & \\
\hline
\end{tabular}

\section{Housing Scenario of Agate Workers}

Majority (46\%) of the workers have a Kachcha house with clay roof tiles. Followed by Pakka Small House (35.6\%). The remaining workers lived in different housing typology (See Table 6). More than $69 \%$ of the house had basic facilities such as water, electricity, toilet and sewer lines. The remaining distribution of the type of basic facilities available to the worker in the house is distributed in different combinations for more details see the table 7.

Table 6 Housing Typology of Agate Workers

\begin{tabular}{|l|c|c|c|}
\hline & $\begin{array}{c}\text { Frequency } \\
\text { (No. of Workers) }\end{array}$ & $\begin{array}{c}\text { Percent } \\
\text { (Housing Typology) }\end{array}$ & Cumulative Percent \\
\hline
\end{tabular}


Towards Excellence: An Indexed, Refereed \& Peer Reviewed Journal of Higher Education / Mr. Mahesh Patel \& Dr. J.G. Rangiya / Page 215-228

\begin{tabular}{|l|r|r|r|}
\hline Kachcha House & 40 & 13.4 & 13.6 \\
\hline Kachcha with Clay Tile Roof & 137 & 46.0 & 60.2 \\
\hline No House & 2 & .7 & 60.9 \\
\hline Pakka Big House & 9 & 3.0 & 63.9 \\
\hline Pakka Small House & 106 & 35.6 & 100.0 \\
\hline Total & 294 & 98.7 & \\
\hline Total & 298 & 100.0 & \\
\hline
\end{tabular}

Table 7 Basic Facilities in the House

\begin{tabular}{|l|r|r|r|}
\hline & \multicolumn{1}{|c|}{$\begin{array}{c}\text { Frequency } \\
\text { (No. of Workers) }\end{array}$} & $\begin{array}{c}\text { Percent } \\
\text { (Basic Facilities) }\end{array}$ & Cumulative Percent \\
\hline Water & 5 & 1.7 & 1.7 \\
\hline Water and Electricity & 9 & 3.0 & 4.7 \\
\hline Water, Electricity and Sewer Line & 2 & .7 & 5.4 \\
\hline Water, Electricity and Toilet & 70 & 23.5 & 29.2 \\
\hline Water, Electricity, Toilet and Sewer Line & 206 & 69.1 & 99.0 \\
\hline Water, Toilet and Sewer Line & 295 & 99.0 & 100.0 \\
\hline Total & 3 & \\
\hline
\end{tabular}

Apart from the basic facilities certain houses had extra facilities in various combinations. $20.8 \%$ of the agate workers had access to TV, LPG and Kitchen combined. Few workers just had TV, or TV and AC, etc.

As many of the workers are working in the agate industry within their own house. It is important to understand what facilities are available to the agate worker for agate work in various combinations. Majority 37.6\% of the workers had access to Machinery, Electricity, Water, and Security tools for the workers in one set of combination. The distribution of such facilities is considerably found in combination with other facilities to understand the situation please refer to the table 8 .

Table 8 Facilities Available for Agate Work within House

\begin{tabular}{|l|r|r|r|}
\hline & $\begin{array}{c}\text { Frequency } \\
\text { (No. of Workers) }\end{array}$ & $\begin{array}{c}\text { Percent } \\
\text { (Basic Facilities } \\
\text { within house) }\end{array}$ & Cumulative Percent \\
\hline Machinery, Electricity and Water & 83 & 27.9 & 27.9 \\
\hline Machinery, Electricity, Water and Security Tools & 112 & 37.6 & 65.4 \\
\hline Machinery and Security Tools & 4 & 1.3 & 66.8 \\
\hline Machinery & 9 & 3.0 & 69.8 \\
\hline Machinery, Electricity, Water, Security Tools and & 13 & 4.4 & 74.2 \\
Vehicle & 10 & 3.4 & 77.5 \\
\hline Machinery, Electricity, Water and Vehicle & 33 & 11.1 & 88.6 \\
\hline Electricity and Water & 27 & 9.1 & 97.7 \\
\hline Electricity, Water and Security Tools & 5 & 2 & 99.3 \\
\hline Electricity, Water, Security Tools and Vehicle & 298 & 100.0 & 100.0 \\
\hline Water, Security Tools and Transport & 2 & 7 & \\
\hline Total & & & \\
\hline
\end{tabular}

\section{Expectations of Agate Workers in Different Situations}

Questions were asked with regards to expectations they hold in different scenario. $92.3 \%$ of the agate workers fully agreed for economics support at times of crisis. $50 \%$ of the agate 
work fully agreed for having an economical support for buying professional tools for agate work. $56.7 \%$ of the total sample size of agate workers, fully agreed to have economical support for buying of safety equipment for agate work. 37.6\% and 55.7\% Fully Agree and Agree respectively for educational support for children of Agate Workers. 54.9\% of the agate workers surveyed fully agreed for requiring support for providing alternative work opportunity than agate work. Agate workers surveyed at time of survey, $49 \%$ of them agreed that they were not satisfied with the current work support they are getting from agate industry.

\section{Economic Scenario of Agate Workers}

Shockingly $89.6 \%$ of the workers fully agreed that they are paid very minimally and their wage rate is quite low. Compared to other types of work. $54.7 \%$ of the agate workers fully agreed that they lack regular work opportunity for their daily livelihood. 55\% of the agate workers surveyed agreed that they were facing issues with regards to family maintenance expense. $47.7 \%$ of the workers found problems with regards to children's education opportunity. $48 \%$ of the people surveyed from agate workers fully agreed that they are having issues with regards to healthcare expense. $60.7 \%$ of the agate workers surveyed fully agreed that they are facing troubles with household economy.

\section{Political Scenario of Agate Workers}

$90.9 \%$ of the people did fully agreed that they were not getting an alternative daily work opportunity apart from the agate work. $49 \%$ fully agreed that government policy is being a hindrance to their local business. $38.6 \%$ agreed that government is not giving enough encouragement to agate industry as compared to other business. $47.3 \%$ agate workers agreed that agate business is not providing proper healthcare and safety facilities. $47.8 \%$ fully agreed that government is not providing agate business enough economic opportunity or help. $40.6 \%$ fully agreed that government is not providing them any insurance, credit or economic support in the times of crisis. 83.6\% agate workers surveyed said yes that agate business create economic inequality. 59\% agate workers surveyed said yes that the agate business creates instability in social bond of a community. 57.4\% agate workers surveyed said no that agate business doesn't affect their social happiness. $67.8 \%$ agate workers surveyed said yes that agate business does affect children marriage.

\section{Health Scenario of Agate Workers}

95\% of the surveyed sample said yes that they are aware about silicosis. $64.1 \%$ of the surveyed sample said no that they are not satisfied with the steps they have taken for prevention of silicosis. $97 \%$ of the surveyed sample said No that there were no death till date because of silicosis. On average there was just 1 death out of total sample size. $100 \%$ of the surveyed sample said No that government did not give any help to the family of dead person. $92.6 \%$ of the surveyed sample said no that they don't feel safe in spite of threat of silicosis. $50.3 \%$ of the surveyed sample said that they did not have any health facilities for regular health check-up. $99.3 \%$ of the surveyed sample said no that they do not have any healthcare transportation facilities like ambulance. 


\section{Solutions and Strategies for Agate Workers}

This section of the paper talks about various strategies that can be adapted for agate industries based on the agate workers inputs. There are five identified strategies by codes A, B, C, D and $\mathrm{E}$. These solutions have been distributed across various forms of solution for individual components such as raw material, government policy, skills etc. but all are aligned towards improving agate industry. Each strategies will be shown and explained under the table based on different components (See Table 9 for more details). So for example if a respondent responded with solutions $\mathrm{A}, \mathrm{B}, \& \mathrm{D}$ that means s/he have suggested three different solutions for the particular component. Since there are various combinations of solutions suggested by the respondents over here in this paper we are just looking at top three solutions that are recorded based on the percentage.

Table 9 Solutions Suggested by Workers

\begin{tabular}{|c|c|c|}
\hline Sr.No & Area of Interest & Strategies and its Codes \\
\hline 1 & Raw Material & $\begin{array}{l}\text { (A) Buy Yourself, (B) Common Market, (C) Loan Facility, (D) Accessible, (E) } \\
\text { Affordable Transportation }\end{array}$ \\
\hline 2 & Machinery & (A) Silicosis-Dust Free, (B) More Productive, (C) Modern, (D) Easy Availability \\
\hline 3 & Government Policy & $\begin{array}{l}\text { (A) Supportive in Exporting And Importing, (B) Loan And Accident Insurance, (C) } \\
\text { Tax Benefits, (D) Developed as a Heritage Industry }\end{array}$ \\
\hline 4 & Market & $\begin{array}{l}\text { (A) Available Local-Domestic Market, (B) Planning for Agate Handicraft Fair, (C) } \\
\text { Advertising, (D) Marketing }\end{array}$ \\
\hline 5 & Daily Work & $\begin{array}{l}\text { (A) Minimum Wage, (B) Shed And Workshop Base Work, (C) Developed GIDC } \\
\text { And Agate Work Zone, (D) Developed Agate related another Sector } \\
\text { Development }\end{array}$ \\
\hline 6 & Skills & $\begin{array}{l}\text { (A) Training for New Technology and Machinery, (B) Training for Other Sector } \\
\text { related to Agate Work, (C) Modern Machinery }\end{array}$ \\
\hline 7 & $\begin{array}{l}\text { Healthcare and } \\
\text { Safety }\end{array}$ & $\begin{array}{l}\text { (A) Silicosis-Dust Free Machinery, (B) Regular Health Check-up, (C) Medi-Clam } \\
\text { And Health Insurance, (D) Eco-Friendly Technology }\end{array}$ \\
\hline 8 & $\begin{array}{l}\text { Environmental } \\
\text { Problems }\end{array}$ & $\begin{array}{l}\text { (A) Dust Free Mdust Free Machinery, (B) Developed GIDC And Agate Work Zone, } \\
\text { (C) Proper Shed and Workshop Development }\end{array}$ \\
\hline 9 & $\begin{array}{l}\text { Infrastructural } \\
\text { Facilities }\end{array}$ & $\begin{array}{l}\text { (A) Economic Assistance for Agate Industry, (B) Consolation in Electricity For } \\
\text { Agate Work, (C) Accident/Health Insurance, (D) Waste Material Disposal } \\
\text { Methods, (E) Affordable Transportation }\end{array}$ \\
\hline
\end{tabular}

Top three solutions suggested by respondents for the following -

1. Raw Materials: $15.4 \%$ of the respondent went with the strategy A \& C combine. Followed by combination of B \& C at $14.4 \%$ and A \& D at $12.8 \%$.

2. Machinery: A \& $\mathrm{C}$ combination is at $13.8 \%, \mathrm{~A} \& \mathrm{D}$ at $11.4 \%$ and $\mathrm{B} \& \mathrm{C}$ combined at $11.1 \%$.

3. Government Policy: A \& D and B \& C are tied at $13.4 \%$, followed by A \& C at $11.7 \%$ and $11.4 \%$ wants $C \& D$ combo.

4. Market: $\mathrm{A} \& \mathrm{C}$ at $17.1 \%, \mathrm{~A} \& \mathrm{D}$ at $15.4 \%$ and $\mathrm{B} \& \mathrm{C}$ at $10.7 \%$.

5. Daily Work: $16.8 \%$ went with A \& C combination, followed by $14.1 \%$ for A \& D and $13.8 \%$ for B \& C combined.

6. Skills: $16.4 \%$ went with B \& C combined, $13.4 \%$ wants A \& B and $12.4 \%$ wants C \& D.

7. Healthcare and Safety: A \& C got $11.7 \%$ agreement, For A \& D it is $11.1 \%$ and B \& C combined at $10.4 \%$. 
8. Environmental Problems: $15.4 \%$ for A \& C, $14.1 \%$ for A \& D and $12.4 \%$ for B \& C.

9. Infrastructural Facilities: $16.4 \%$ wants A \& D, A, B \& D plus A \& C are tied at $12.1 \%$ and $\mathrm{A} \& \mathrm{E}$ combined at $11.4 \%$.

\section{- CONCLUSION AND DISCUSSION}

Agate industry and the problem of silicosis is not just about a disease, but it is also about a dignity of the workers and the way they are treated in the process and how their socioeconomic conditions are affected because of the silent disease. Silicosis has been silently killing people from more than 50 years in the Khambhat region and there is no respite from the death. The industry has largely been a household industry in the Gulf of Khambhat region where the agate process includes heating, chipping, grinding drilling and polishing for various purpose. The mineral dust i.e. the Silica dust produced in the process creates the problem of silicosis.

The agate workers in the agate industry work under a manufacture or a middleman and most of the work from their own home. Where usually the entire family members are also engaged in the process of agate making. Whether the work is carried in a factory or it is takes place inside the house both the workplace leads to silicosis. The workers who work from home sell their work to the traders on daily basis and collect the revenue from it because it is something that keeps their livelihood running but at risk of death.

No place on the planet the workers might join such kind of work environment where death is inevitable for them as well as their predecessors. The impulse of such decision uncovers the gravity of neediness. One can enter the industry only at the assurance of meeting death. The workers environment has not been improved since last couple of decades even though many studies have shown the seriousness of the issues there has been no proper steps taken by the government, traders, factory owners and middlemen for protecting the worker from dying. There is lack or indifference among the stakeholders who are supposed to protect the workers but are not doing so instead they are exploiting and taking the advantage of weak law within the state for their own profits. Subject to human rights is out of question for the worker providers. The government is yet to take a stringent and strict decisions on the rules and regulations of hazardous diseases like silicosis which change the socio-economic background of a human being until he or she dies.

The best way to prevent silicosis is to identify the activities in the workplace that crates crystalline silica dust and then to eliminate or control the dust with exhaust system or water spray method, also the dust can be controlled through dry air filters. The exhaust system should be based on National Institute of Occupational Health (NIOH) recommendations. As per the NIOH studies the major source of dust in the agate industry is from the grinding process. NIOH developed an exhaust system, the device can reduce the dust by $94 \%$. The design was created in a way that it did not interfere with the work of the workers. The issue that was majorly reported was excessive power consumption. In order to resolve the issue of excessive power consumption without compromising the dust control efficiency the device was redesigned in the grinder. Currently many small units possess such device. 
The employees should be issued with the identity cards. Workers welfare fund needs to be created with the help of state government and the traders. If required the fund should be legislated as an act. The fund should consider various stakeholders across organizations, traders, workers organization, NGOs and Government. The person who is affected by silicosis should be treated in the Primary Health Care and issued a health card for the same. The Primary health care should be available to the workers $24 \times 7$. Since these kind of provisions are yet not available to workers in the agate industry they are desperate and eager to get themselves employed in different industries which can help sustain their daily livelihoods. But they are unable to do so because there is no scope or hope provided to them for alternative employment opportunity. The credit trap that workers fall into makes it even harder or impossible to change their occupation. The traders and manufactures lure the workers into a debt trap by providing those loans without any interest. The workers who are lured and have taken loan are paid less wages from the manufacture or the trader. Piece rate is different for agate workers who are into debt. The workers are not free or allowed to change occupation till they fully repay the debt they have taken, thus creating a scenario of bonded labour. The workers are absolutely scared of the employer since they can face tremendous amount of pressure from the. In case of the workers death, the family members are forced to work and repay the debt. Under these kind of situation the family is forced to join the agate industry.

These workers are not able to access any compensation from injuries at working including silicosis. There is no well-defined employer-employee relationship because of this perspective the laws and regulations are not able to cater to the problem of silicosis and it has become a loophole which the traders and manufacture use at their advantage to exploit the agate workers in the Gulf of Khambhat region. Neither of these compensation are covered under ESI act. There has been no legal reforms for silicosis till than the government should provide or pay lump sum compensation to the agate workers who are dying because of silicosis. But even that is yet to be done in the case of Gulf of Khambhat region. The economic relationship between the workers and traders need to be changed. Traders are the ones who are investing in the raw material, then out sourcing it to the manufacturing units to the agate workers and middlemen especially the work of polishing, which is one of the most hazardous work among the agate industry. The traders get away without any responsibilities since there is no bylaw or regulations that puts them under pressure to provide facilities and equipment to the agate workers.

The shades of the agate may entrance us however it takes away the shades of the lives of the workers and family. Gujarat is extremely glad for the agate business yet has never given careful consideration to the labourers and the workers who are walking on the death bed of silicosis.

\section{- REFERENCES}


Towards Excellence: An Indexed, Refereed \& Peer Reviewed Journal of Higher Education / Mr. Mahesh Patel \& Dr. J.G. Rangiya / Page 215-228

Agate, A. C. (2007, July 16). Gem. Retrieved Febraury 24, 2018, from Agate Creek Agate: https://web.archive.org/web/20070716052933/http://www.gem.org.au/agate.htm

BHAN, J. M. (n.d.). Sidis and the Agate Bead Industry of Western India . 61 - 80.

Changrani, R. (2016, March 9). Jewelinfo4u. Retrieved February 24, 2018, from Jewelinfo4u website: https://www.jewelinfo4u.com/important-agate-mines-in-the-world

Charles Kernaghan, B. B. (2010). HEARTS OF DARKNESS. Pittsburgh: National Labor Committee 5 Gateway Center, 6th Floor Pittsburgh, PA 15222.

Deepak B Sharma, T. A. (2011). STUDY ON WORK RELATED FACTORS OF AGATE GRINDERS IN SHAKARPURAKHAMBAT, GUJARAT . NATIONAL JOURNAL OF COMMUNITY MEDICINE 2011 Volume 2 Issue 1, 60 - 63.

Gujarat, V. (2017, January 10). Vibrant Gujarat. Retrieved February 24, 2018, from http://vibrantgujarat.com: http://vibrantgujarat.com/writereaddata/images/pdf/gems-jewellerysector.pdf

Harrison, T. (2009). ALICE AND AGATE COURTS HISTORIC DISTRICT . NEW YORK CITY: NEW YORK CITY LANDMARKS PRESERVATION COMMISSION.

India, C. o. (2011). DISTRICT CENSUS HANDBOOK ANAND PART-XII- A \& B. DIRECTORATE OF CENSUS OPERATIONS .

JAGDISH PATEL, M. R. (2011). THE AGATE INDUSTRY AND SILICOSIS IN KHAMBHAT, INDIA. NEW SOLUTIONS, Vol. 21(1) , 117 - 139.

KING, C. W. (1867). NATURAL HISTORY OF PRECIOUS STONE AND OF THE PRECIOUS METALS. LONDON: BELL \& DALNY, YORK STREET, COVENT GARDEN, CAMBRIGE: DEIGTON, BELL \& CO.

KUNZ, G. F. (1890). GEMS AND PRECIOUS STONES OF NORTH AMERICA. NEW YOURK: THE SCIENTIFIC PUBLISHING COMPANY .

Lakho J. Bhagia, H. G. (2008). COAST-BENEFIT ANALYSIS OF INSTALLING DUST CONTROL DEVICES IN THE AGATE INDUSTRY, KHAMBHAT (GUJARAT). Indian Journal of Occupational and Environmental Medicine, Volume 12 - Issue 3, 128 -131.

LINDQVIST, K. A. (1998). Agate as an indicator of impact structures: An example from Saaksjarvi, Finland . Meteoritics R Planetary Science 33, 7 - 12.

LucynaNatkaniec-Nowak 1, M.-S. 1. (2016). Agates from Kerrouchen (The Atlas Mountains, Morocco): Textural Types and Their Gemmological Characteristics. MINERALS, 1-13.

NAYANJEET CHAUDHURY, A. P. (2010). SILICOSIS AMONG AGATE WORKERS AT SHAKARPUR:AN ANALYSIS OF CLINIC-BASED DATA. LUNGI INDIA, 221 - 224.

Olson, D. W. (2000). GEMSTONES. U.S. GEOLOGICAL SURVEY MINERALS YEARBOOK, 32.1 32.5 .

PETRANEK, J. (2004). Gravitationally banded (“Uruguay-type") agates in basaltic rocks - where and when? Bulletin of Geosciences, Vol. 79, No. 4, 195 - 204. 
Towards Excellence: An Indexed, Refereed \& Peer Reviewed Journal of Higher Education / Mr. Mahesh Patel \& Dr. J.G. Rangiya / Page 215-228

Possehl, G. L. (1981). Cambay Beadmaking - An ancient craft in modern India. Ahmedabad: Expedition.

POSSEHL, G. L. (1981). CAMBY BEADMAKING AN ANCIENT CRAFT IN MODERN INDIA. EXPENDITION, 39-47.

PT, G. (2013, June 12). Ritimo. Retrieved February 24, 2018, from ritimo.org: http://www.ritimo.org/The-Silent-Killer-Agate-Workers-in-Khambat-Fight-against-Silicosis

RANGIYA, J. Y. (2007). CERAMIC INDUSTRY IN GUJARAT - A GEOGRAPHICAL ANALYSIS. AHMEDABAD: GUJARAT UNIVERSITY LIBRARY.

Sponsored by Friends of Mineralogy, C. C., \& Daniel Kile, T. M. (2005). Symposium on Agate and Cryptocrystalline Quartz. Colorado: Colorado School of Mines Geology Museum; and U.S. Geological Survey.

U.S. Department of the Interior, N. P. (2009). Agate Fossil Beds National Monument . Colorado: Geologic Resources Division Natural Resource Program Center P.O. Box 25287 Denver, Colorado 80225.

Vincent, D., \& Gupta, G. (2002). Critical Habitat Information system for Gulf of Khambhat-Gujarat. Chennai: GoI Department of Ocean Development.

WODISKA, J. (1909). A BOOK OF PRECIOUS STONES. NEW YORK AND LONDON : G. P. PUTNAM'S SONS, THE KNIKERBOCKER PRESS.

\title{
Mahesh Patel
}

Assistant Professor

Department of Geography

School of Science

Gujarat University, Ahmedabad - 380009.

Email: mkpate10077@gmail.com

Mob. No. 91+9426242680

$\&$

\author{
Dr. J. G. Rangiya \\ Associate Professor \\ Department of Geography \\ Uma Arts \& Nathiba Commerce Mahila College \\ Gandhinagar - 382024. \\ Email: jaymalsavlas@gmail.com \\ Mob. No. 91+ 9426999174
}

